\title{
DISSATISFACTION FACTORS THAT INFLUENCE CUSTOMERS TO GIVE LOW ONLINE RATING TO HOSPITALS
}

\author{
Arif Raza, Ranjit Kumar Dehury \\ 1. Goa Institute of Management, Sanquelim, Goa, India \\ 2. School of Management Studies, University of Hyderabad, Telangana, India
}

Correspondence: arifraza@rediffmail.com

\begin{abstract}
The study attempts to identify factors of dissatisfaction that significantly influence customers to give low rating to the hospital on online platforms, based on the context of India. The study conducts a qualitative analysis of a sample of 669 reviews given to private for-profit hospitals on online platform. Through textual analysis of the reviews, five distinct factors of dissatisfaction were identified. Each factors were statistically tested to identify those that were significantly present in reviews that gave low rating to the hospital. Three out of five factors, inferior medical care, inappropriate behaviour of staff and profiteering attitude, were found to be significant. Within these three factors no significant difference was found in their strength of association with the low online rating.
\end{abstract}

\section{KEYWORDS}

Dissatisfaction of client, Healthcare domain, Hospital assessment, Online rating, Online reviews of hospital, Word of Mouth

\section{INTRODUCTION}

Private for-profit hospitals earn revenue from patients and rely considerably upon its image in patient community to sustain and grow their business. Several studies have shown that word of mouth (WOM) plays an important role for rousing publicity and enhancing the business of hospital $(1,2)$. Of late, the image building process was inevitable for the hospitals by using online rating mechanism on established reviewing platforms. The Internet services, social media platforms and world wide web has opened opportunities for active customers to communicate and influence effectively in an open market (3). Overwhelming use of electronic WOM (e-WOM) is found in Indian hospitals arena.
Healthcare in India is delivered by public hospitals, private not-for profit and private for-profit hospitals. While public hospitals and private not-for profit hospitals are free or heavily subsidized for all patients, the facilities and quality of care at these hospitals has been generally considered as poor. [4,5] This has led to a thriving private for-profit hospital industry that provide better facilities and customer services to attract patients. [6] Most people prefer such hospitals for their medical care, if finance is not a limitation. The private for-profit hospitals in India range from low cost small individual owned hospitals to large and expensive corporate run hospitals. Last one decade has seen rapid increase in the number of corporate hospitals in India, specifically in urban areas. This has intensified the 
competition and steered the corporate hospitals to utilize marketing tools, including online marketing.

With increase in private hospitals in cities, Indian customers often have a choice when it comes to selecting a private hospital for a treatment. High penetration of internet in urban areas of the country, [7] rating and reviews shared online by other patients, has become a key source of information and decision making for most customers seeking healthcare services in private hospitals. While there is no platform specifically for hospitals, most customers share their reviews and rating of hospital on Google reviews. A check on number of feedbacks about hospitals available on Google reviews system indicates that, there is noteworthy increase of $200 \%$ ratings over last five years. The corporate giants in hospital sector like Fortis, Apollo, Narayana Hrudalaya, Yashoda, Global and Continental by and large started to respond online customer review, which usher the new age of publicity and image building. The increasing popularity of online rating force the necessity of hospital chains and standalone quality facilities to understand the customer. They also rectify things based on online reviews.

There are research gaps to understand the details of what impacts low rating of a hospital and how value chain is determined by customers of hospitals. There is need to understand thematically what transpires the rating of the hospitals. This paper is an effort to delineate the determinants for of client dissatisfaction which leads to low rating for a particular hospital. The study adopt secondary research methodology by analysing publicly available online Google reviews. The reviews were analysed by making various themes and understanding the association of various factors.

\section{REVIEW OF LITERATURE:}

Evidences across the world confirm that there are strong association of WOM with the business in health sector. According to a study by Fergusen et al. [1] it is confirmed that WOM endorsement found to be an effective marketing strategy for hospitals. Therefore, the hospitals use this strategy widely to attract patients. International medical patients were found to be influenced by friends, family, relatives and doctor's referral in a study conducted in Malaysian hospitals. [2] The study also recommend to act on the analytics of word like WOM. Another similar study by Cheung et al. [8] gives emphasis on the driving forces like physician's referral and WOM as significant factors for attraction of patients. Before several decades WOM cannot reach to masses, it only influence close relatives and family friend. However, with the wide spread use of internet the gap in communication with far off people was minimized to a great extent. This usher to a new era of Online Customer reviews (OCR). The OCR empowers would-be customers to become more informed about various goods and services like medical care. A study exploring effect of e-WOM on sales [9] found that the effect of OCR regarding product, price and brand is heavily influenced by valence and moderated by volume and variance of reviews. In another similar study, [10] it was reported that influential OCR put pressure on customers to purchase goods and services. In a study that looked into how sales of book on Amazon is affected by online reviews, [11] Gao et al. found that the higher volume of OCR and better valence improve relative sales. Another study exploring how brand strength matters in light of positive and negative reviews described that the impact of Positive (negative) reviews help in the effect of increase (decrease) about the sales of relatively weaker brands. [12]

The research gaps galore when there is less studies found on the review of services of healthcare providers. In one study where 5 years data of online rating of physician by their patients was analysed [13] it was found that the electronic physician rating increases and a common place for the public has been created. Another study which looked into patient experience and satisfaction, [14] identified 13 dimension of patients on a platform of physician rating which influence to a great extent. The research in the field of online reviews confirm that valence play an important role in the informed choice of customers. Evidence also emerge that negative and positive review influence differently, with negative reviews having higher impact. [15,16] Hence, negative reviews and rating should be given more attention while assessing OCR.

Least online rating influence valence. There is a need to know the mind of customers for the providing low rating. There are few studies to understand factors that influence online reviews and rating of hospitals. No study reported specific relationship of low rating and OCR which. The understanding of this phenomena may help the hospital to improvise these services to a great extent.

\section{METHODOLOGY}

The study was done using qualitative analysis on descriptive feedback provided by customers online about hospitals. 
The descriptive feedback were decomposed by coding them into various factors. Frequency of occurrence of each factors was calculated in all feedback. Each factor was tested statistically to examine significant association with feedback that gave low rating to the hospital.

\section{CONTEXT OF THE STUDY:}

In India, online reviews and rating of hospitals are largely available on google platform. The platform allows anyone to write a descriptive review about any hospital, available on google platform, and rate the hospital out of five stars, with more stars indicating good feedback. Based on all ratings received, Google provides an aggregate rating of the hospital. While rating the hospital is necessary to submit the feedback, writing descriptive review is optional and a blank space is provided to write in a free form, with unrestricted length. Through a quick observation of 150 random reviews, it was found that there is a high variance in length of description and several feedback submitted did not had any description. Average length of description were 93 words with standard deviation of 57 . Since the study aims to identify significant factors associated with lower rating, only those feedback that had description of a sufficient length was considered for analysis.

\section{DATA:}

A two-stage sampling was done to select a sample of online reviews that served as data for this study. In first stage a set 39 hospitals were selected. Only private for-profit hospitals, which are operational for more than a year were included in the study, to ensure that they are comparable and their online rating and reviews are minimally affected by confounding factors. The hospitals were stratified across north, south, east and west zones of the country, so that the findings could be generalized. Hospitals which were not present on Google review platform or have received very less ratings (less than 30), were excluded. In second stage, reviews of the selected hospitals were randomly extracted from Google reviews, after excluding reviews that had less than 10 words or are written in language other than English or Hindi. Reviews with corresponding rating of 5 stars were also excluded with an assumption that these customers would be completely satisfied, have no complaints and thus their descriptive feedback cannot be used for identifying dissatisfaction factors. A description of final mix of sampled data is given in Table 1 .

\section{TABLE 1: SAMPLE MIX}

\begin{tabular}{|l|l|}
\hline Total number of hospitals & 39 \\
\hline Proportion of hospitals from & $23.1 \%, 28.2 \%, 28.2 \%$ and \\
North: South: West: East & $20.5 \%$ \\
\hline Total number of reviews & 670 \\
\hline Proportion of reviews from & $24.3 \%, 39.3 \%, 17.5 \%$ and \\
North: South: West: East & $19 \%$ \\
\hline
\end{tabular}

\section{ANALYSIS:}

Texts in the description of sampled reviews were assessed to identify factors that were suggestive of reason for dissatisfaction of the customer who wrote the review. First round of textual analysis yielded 17 factors, which after assessing for distinctiveness, were combined into final five factors. These were inferior medical care, inappropriate behaviour of staff, system and infrastructure inadequacy, money-mindedness of hospital, and high perceived cost. Table 2 explains the meaning of these factors with illustration of texts that were used to identify them.

TABLE 2: FACTORS SUGGESTIVE DISSATISFACTION IDENTIFIED THROUGH TEXTUAL ANALYSIS OF SAMPLED REVIEWS

\section{DISSATISFACTION FACTORS}

\begin{tabular}{|c|c|}
\hline Inferior medical Care & $\begin{array}{l}\text { Reviews suggestive of discontent of the customer with one or more of following } \\
\text { - Credentials of healthcare providers, } \\
\text { - Medical care given } \\
\text { Illustration: } \\
\text { "Nurse didn't know how to apply IV and pricked my baby } 4 \text { to } 5 \text { times" } \\
\text { "Doctor messed it up and finally my father died" }\end{array}$ \\
\hline $\begin{array}{l}\text { Inappropriate Behaviour of } \\
\text { staff }\end{array}$ & $\begin{array}{l}\text { Reviews suggesting that customers were unhappy with any of the following } \\
\text { - } \quad \text { Behaviour of staff towards patient and/or his/her family members. } \\
\text { - } \quad \text { Attention given to the patient. }\end{array}$ \\
\hline
\end{tabular}




\section{DISSATISFACTION FACTORS EXPLANATION}

\begin{tabular}{|c|c|}
\hline & $\begin{array}{l}\text { - Level of support provided; } \\
\text { - Empathy } \\
\text { Illustration: } \\
\text { "They don't even listen and return patient saying that doctor do not meet without } \\
\text { appointment" } \\
\text { "They don't even tell us what is happening with our patient" }\end{array}$ \\
\hline $\begin{array}{l}\text { System and infrastructure } \\
\text { inadequacy }\end{array}$ & $\begin{array}{l}\text { Indication of problems faced on account of infrastructure, facilities and systems of } \\
\text { hospitals, such as } \\
\text { - Inconvenient location of the hospital } \\
\text { - Poor infrastructure and maintenance of the facility; } \\
\text { - Hime-consuming and non-user friendly processes } \\
\text { - Unreasonable policies } \\
\text { Illustrations: } \\
\text { "The front staff is inefficient. They should at-least hire someone who is good in } \\
\text { speaking English language" } \\
\text { "Nobody picks the phone. I had to do multiple rounds to get my investigation } \\
\text { reports" }\end{array}$ \\
\hline Money-mindedness & $\begin{array}{l}\text { Reviews indicating the perception that hospital, or it's authorities are more } \\
\text { interested in making money rather than patient's health. } \\
\text { Illustration, } \\
\text { "They do cheating if patient is insured" } \\
\text { "They just see patient as money making opportunity" }\end{array}$ \\
\hline High perceived price & $\begin{array}{l}\text { Reviews that indicates that the reviewer perceived pricing to be hospital on higher } \\
\text { side and difficult to afford. } \\
\text { Illustration, } \\
\text { "The final bill amount was very high. Difficult to afford" } \\
\text { "Looks good externally, but will cut your purse down bit by bit" }\end{array}$ \\
\hline
\end{tabular}

To identify which of these factors where significantly associated with low corresponding ratings, each factor was hypothesized to be individually significant enough for causing the reviewer give low rating to the hospital. The hypothesis was statistically tested for each factor, and their strength of association with low rating was compared.

\section{STATISTICS:}

To conduct the statistical analysis a frequency count of presence of each factor in feedback with different ratings was done. For hypothesis stating significance of each factor was tested using Chi square test of independence. For each factor, the sample of reviews where classified in two groups, based on whether the factor was present or not. This was done after controlling for presence of rest of the factors, to avoid its effect on rating. Under each group, proportion of reviews that had low rating was calculated. For this purpose only 1 star rating was considered as low rating. The data was plotted on a table with $4 \times 2$ matrix. $p$ value and residual value was calculated using post hoc chi square test of association. 
After identifying significant factors they were compared using Chi square test of association to identify if the effect of factors significantly differ with each other.

\section{FINDINGS}

Descriptive statistics of qualitative analysis is presented first followed by inferential statistics to test the hypothesis. The findings are discussed in light of other research evidences, and a conclusion is presented.

\section{DESCRIPTIVE STATISTICS:}

Frequency and distribution of all five factors of dissatisfaction was calculated as per the methodology stated. Out of 670 reviews in the sample, 77 reviews were inconclusive as the text written in reviews were meaningless or unrelated to the hospital. Out of remaining 593 reviews, in $19.2 \%$ none of the dissatisfaction factors were observed, $53.3 \%$ of reviews had more than one and $53.3 \%$ had just one dissatisfaction factor. Table 3 present a description of reviews in the sample and Table 4 presents the rating-wise spread of reviews.

\section{TABLE 3: DESCRIPTION OF REVIEWS UNDER SAMPLE}

\begin{tabular}{|l|l|}
\hline Total reviews in sample & 670 \\
\hline Number reviews analysed, after eliminating inconclusive reviews & 593 \\
\hline Total count of dissatisfaction factors in all reviews (n) & 669 \\
\hline Reviews with 1 star rating & $34.90 \%$ \\
\hline Reviews with 2 star rating & $17.80 \%$ \\
\hline Reviews with 3 star rating & $14.40 \%$ \\
\hline Reviews with 4 star rating & $32.90 \%$ \\
\hline Average number of dissatisfaction factor found per review & 1.13 \\
\hline Reviews with no dissatisfaction factor & $19.20 \%$ \\
\hline Reviews with just one dissatisfaction factor & $53.30 \%$ \\
\hline Reviews with 2-3 dissatisfaction factor & $36.80 \%$ \\
\hline Reviews with more than 3 dissatisfaction factors & $9.90 \%$ \\
\hline
\end{tabular}

TABLE 4: RATING-WISE DISSATISFACTION FACTORS IN ONLINE REVIEWS

\begin{tabular}{|c|c|c|c|c|c|}
\hline & 1 STAR & 2 STAR & 3 STAR & 4 \\
\hline & & $N=469$ & $\mathbf{N}=\mathbf{8 3}$ & $N=54$ & $N=54$ \\
\hline Inferior medical Care & $n=105$ & $\begin{array}{l}19.8 \%^{*} / \\
88.6 \%{ }^{\#}\end{array}$ & $9.6 \% / 7.6 \%$ & $7.4 \% / 3.8 \%$ & $0.0 \% / 0.0 \%$ \\
\hline $\begin{array}{l}\text { Inappropriate Behaviour of } \\
\text { staff }\end{array}$ & $n=157$ & $\begin{array}{l}27.1 \% / \\
80.9 \%\end{array}$ & $\begin{array}{l}20.5 \% / \\
10.8 \%\end{array}$ & $9.3 \% / 3.2 \%$ & $\begin{array}{l}12.7 \% / \\
5.1 \%\end{array}$ \\
\hline $\begin{array}{l}\text { System and infrastructure } \\
\text { inadequacy }\end{array}$ & $n=192$ & $\begin{array}{l}24.1 \% / \\
58.9 \%\end{array}$ & $\begin{array}{l}39.8 \% / \\
17.2 \%\end{array}$ & $\begin{array}{l}38.9 \% / \\
10.9 \%\end{array}$ & $\begin{array}{l}39.7 \% / \\
13.0 \%\end{array}$ \\
\hline Money-mindedness & $n=122$ & $\begin{array}{l}22.6 \% / \\
86.9 \%\end{array}$ & $\begin{array}{l}13.3 \% / \\
9.0 \%\end{array}$ & $9.3 \% / 4.1 \%$ & $0.0 \% / 0.0 \%$ \\
\hline High perceived price & $n=93$ & $\begin{array}{l}6.4 \% / \\
32.3 \%\end{array}$ & $\begin{array}{l}16.9 \% \\
15.1 \%\end{array}$ & $\begin{array}{l}35.2 \% / \\
20.4 \%\end{array}$ & $\begin{array}{l}47.6 \% / \\
32.3 \%\end{array}$ \\
\hline
\end{tabular}

* Percentage with total dissatisfaction factors observed in 1 star rated reviews

\# Percentage with total occurrence of the factor in all reviews 
The rating-wise spread of dissatisfaction factors indicates that occurrence of dissatisfaction factors are higher in reviews with 1 or 2 star rating. Highest proportion of occurrence of 'inferior medical care', inappropriate behaviour of staff' and 'money-mindedness' were observed in reviews with 1 star rating.

\section{STATISTICAL TESTING FOR ASSOCIATION:}

Chi square test of association (post hoc) was used to test if dissatisfaction factor is significantly present in reviews with 1 start rating. As the study intends to examine the association only in cell that describes occurrence of a factor and 1 star rating, the corresponding $p$ value and residual value of that only that cell was considered for drawing inference. In addition, the analysis was focussed only on positive association, the values reflective of negative association was considered as 'no association'. Table 5 presents the statistical values and it's inference for each factor of dissatisfaction

\section{TABLE 5: STATISTICAL VALUES AND INFERENCES FOR EACH DISSATISFACTION FACTOR}

\begin{tabular}{|l|l|l|}
\hline DISSATISFACTION FACTOR & STATISTICAL VALUES & INFERENCE \\
\hline Inferior medical Care & p value 0.00, residual 5.9 & Supports significant presence \\
\hline Inappropriate Behaviour of staff & p value 0.00, residual 5.5 & Supports significant presence \\
\hline $\begin{array}{l}\text { System and infrastructure } \\
\text { inadequacy }\end{array}$ & p value 0.273, residual 1.1 & $\begin{array}{l}\text { Does not supports significant } \\
\text { presence }\end{array}$ \\
\hline Money-mindedness & p value 0.00, residual 6.6 & Supports significant presence \\
\hline High perceived price & p value NA, residual -4.5 & $\begin{array}{l}\text { Does not supports significant } \\
\text { presence }\end{array}$ \\
\hline
\end{tabular}

The statistical analysis show that 'inferior medical care', 'inappropriate behaviour of staff' and 'moneymindedness' are positively associated with the reviewer giving 1 star rating to the hospital. The other two were not found to be significant. In addition, difference in strength of association between significant factors were tested using Chi square test of association. The result shows no significant difference between these three factors (Chi square $8.941, p=0.177$ )

\section{DISCUSSION}

The present study reports some interesting features of Indian customers regarding their choices and ratings on healthcare organizations. The study put primacy on perception of the clients while considering to avail services based on online reviews. Higher the ratings on clinical services, more is the likelihood to avail the services in future. A study in Bangalore, India [17] shows that similar use of Google review provide edge over other hospitals and maintenance of green hospitals
The study identifies that perception of inferior quality medical care provision, poor behaviour and moneymindedness as significant reason for highest level of dissatisfaction amongst Indian customers of hospitals. These findings are in line with findings of few other studies. A study in Saudi Arabia, [18] identified six components that influences choice of hospital, in which perceived quality of medical care was the most prominent one. Several studies [19-21] on patient satisfaction in Indian hospitals has identified staff behaviour and profiteering attitude as prominent reasons influencing patient's satisfaction or dissatisfaction. Most of these studies are done using primary feedback data, where eliminating bias in response is difficult. Online reviews are completely voluntary, anonymous and hence can be assumed to be free of response bias. The findings from this study reinforce the factors of dissatisfaction, which has also been seen in several studies done individual hospitals.

The study also brings out many facets of cultural and socioeconomic parameter while rating the hospitals after 
availing the services through online reviews. There are many interesting aspects on rating relating to the services of hospital and cost involved in the entire process. Few factors play significant role when it comes to selection of a hospital for treatment. Since online reviews are the prominent source of information about hospital, and a major influencer of prospective customers, the hospitals need to act on individual customer's review on case to case basis. Organizational reputation and consumer depends a lot on the review of online health communities. $[22,23]$

The study also reports influence of online reviews on brand value of the hospitals. Unlike traditional hospitals, there is need to be vigilant on the e-WOM in long run brand building process. There is also further need of digging out data by adopting analytics for the improvement of services. Not just Google review but any other review system can be adopted for the analytics purpose regarding the experience of customers. This study also infer that the online systems can be used to notify the reviews to the hospital quality management departments. Hence, decisions regarding market strategy can be taken immediately. It is reported that the private hospitals have to be responsible and adopt new technologies for enhancing their business (23). Further, A study reported from Bangalore that online review help in maintaining the quality of hospital indirectly making the private hospitals responsible. [24)

\section{CONCLUSION}

Online reviews of hospital express various types of negative experiences that a customer of hospital faced. However, few types of experiences significantly results in customer giving low or least rating to the hospital on online platforms. The study concludes that experience of being provided inferior quality clinical care, poor behaviour of staff towards patients and their family and being treated with a money minded attitude are strong enough for a customer to attribute least rating to the hospital. The study also concludes that dissatisfaction expressed with inadequacies in systems and infrastructure and expensiveness of the hospital are not strong enough for customers to give least rating. It can be inferred that level of dissatisfaction vary with types of experiences faced by customers. Thus hospitals can prioritize the negative experience for which customers have low tolerance, and by focusing on the same, low online rating can be avoided.

\section{IMPLICATIONS AND LIMITATIONS:}

The findings from the study can be useful for private forprofit hospitals that competes in a market for increasing their customer base. As explained in the introduction section, online reviews and rating plays a key role in choice that Indian patients make in selection of a private hospitals. Rising competition, makes it important for private hospitals to ensure that they avoid getting low rating from their patients on online platforms. Literature indicates that negative rating has a higher influence on customer's decision making as compared to positive rating. [16,25] This research identifies components that play a significant role in hospital obtaining least rating by its customers. Private hospitals can lower the chance of getting lower rating by taking care of these components. The findings suggest that by focusing on improving the perceived medical care quality, conduct towards patient by healthcare providers and avoiding attitudes that are suggestive of money mindedness, a private hospital can significantly avoid the chance of getting low rating.

The findings of the study however, should be interpreted and applied with some key limitations in mind. Firstly, it is based upon feedback that was freely written by customers on online platform and comprehensiveness of the reviews cannot be assured. Secondly, the effect of positive experience along with negative experiences on rating decision was not factored in by the study. To overcome these limitations, further research study where structured primary feedback is collected from a random sample of customers who gave low rating, is suggested. Additional research exploring each factors identified as significant, will be needed to further classify them. This can be of help to private hospitals in appropriately addressing them.

\section{References:}

1. Ferguson RJ, Paulin M, Leiriao E. Loyalty and positive word-of-mouth: Patients and hospital personnel as advocates of a customer-centric health care organization. Health Mark Q. 2007 Mar 28;23(3):59-77.

2. Yeoh $\mathrm{E}$, Othman $\mathrm{K}$, Ahmad H. Understanding medical tourists: Word-of-mouth and viral marketing as potent marketing tools. Tour Manag. 2013 Feb;34:196-201.

3. Lis B, Neßler C. Electronic word of mouth. Bus Inf Syst Eng. 2014;6(1):63-5.

4. Mahapatra S. A comparative study of service quality between private and public hospitals: Empirical evidences from India. J Med Mark [Internet]. 2013 May 
22 [cited 2021 May 7];13(2):1 15-27. Available from: https://journals.sagepub.com/doi/abs/10.1177/174579 $\underline{0413488777}$

5. Mohanan M, Hay K, Mor N. Quality of health care in India: Challenges, priorities, and the road ahead. Vol. 35, Health Affairs. Project HOPE; 2016. p. 1753-8.

6. Shah U. Private Sector in Indian Healthcare Delivery: Consumer Perspective and Government Policies to promote private Sector. Inf Manag Bus Rev [Internet]. 2010 Dec 15 [cited 2021 May 10];1 (2):79-87. Available from:

https://ojs.amhinternational.com/index.php/imbr/artic le/view/874

7. Digital in India: All the Statistics You Need in 2021 DataReportal - Global Digital Insights [Internet]. [cited 2021 May 10]. Available from:

https://datareportal.com/reports/digital-2021-india

8. Tu HT, Laver JR. Word of mouth and physician referrals still drive health care provider choice. Res Brief [Internet]. 2008 Dec [cited 2020 Apr 17];(9):1-8. Available from:

http://www.ncbi.nlm.nih.gov/pubmed/19054900

9. Kostyra DS, Reiner J, Natter M, Klapper D. Decomposing the effects of online customer reviews on brand, price, and product attributes. Int J Res Mark. 2016:33(1):11-26.

10. Cheung CMK, Lee MKO, Rabjohn N. The impact of electronic word-of-mouth: The adoption of online opinions in online customer communities. Internet Res. 2008;18(3):229-47.

11. Chevalier JA, Mayzlin D. The effect of word of mouth on sales: Online book reviews. Vol. 43, Journal of Marketing Research. 2006. p. 345-54.

12. Ho-Dac NN, Carson SJ, Moore WL. The effects of positive and negative online customer reviews: Do brand strength and category maturity matter? J Mark [Internet]. 2013 Nov 1 [cited 2021 May 7];77(6):37-53. Available from:

https://journals.sagepub.com/doi/10.1509/im.11.0011

13. Gao GG, McCullough JS, Agarwal R, Jha AK. A changing landscape of physician quality reporting: Analysis of patients $\Leftrightarrow$ Online ratings of their physicians over a 5-year period. J Med Internet Res [Internet]. 2012 Jan 1 [cited 2021 May 7]; 14(1). Available from: https://pubmed.ncbi.nlm.nih.gov/22366336/

14. Reimann S, Strech D. The representation of patient experience and satisfaction in physician rating sites. A criteria-based analysis of English- and Germanlanguage sites. BMC Health Serv Res. 2010 Dec 7:10(1):1-14.

15. Chen Y, Wang QI, Xie J. Online social interactions: A natural experiment on word of mouth versus observational learning. J Mark Res [Internet]. 2011 Apr [cited 2021 May 7];48(2):238-54. Available from: /record/2011-06410-003

16. Anderson EW. Customer satisfaction and word of mouth. J Serv Res [Internet]. 1998 Jun 29 [cited 2021 May 7];1 (1):5-17. Available from: https://journals.sagepub.com/doi/10.1177/1094670598 $\underline{00100102}$

17. Dhillon VS, Kaur D. Green hospital and climate change: Their interrelationship and the way forward. J Clin Diagnostic Res [Internet]. 2015 Dec 1 [cited 2021 May 9];9(12):LE01-5. Available from: https://pubmed.ncbi.nlm.nih.gov/26814377/

18. Al-Doghaither AH, Abdelrhman BM, Wahid Saeed AA, Magzoub MEMA. Factors influencing patient choice of hospitals in Riyadh, Saudi Arabia. J R Soc Promot Health [Internet]. 2003 Sep 7 [cited 2021 May 9];123(2):105-9. Available from:

https://journals.sagepub.com/doi/abs/10.1177/146642 $\underline{400312300215}$

19. Jawahar SK. A study on out patient satisfaction at a super specialty hospital in India. Internet J Med Updat [Internet]. $2007 \mathrm{Jul} 1$ [cited 2021 May 9];2(2). Available from:

https://go.gale.com/ps/i.do? $p=H R C A \& s w=w \&$ issn=169 40423\&v=2.1 \&it=r\&id=GALE\%7CA $187844337 \&$ sid=goog leScholar\&linkaccess=fulltext

20. Sharma R, Sharma M, Sharma RK. The patient satisfaction study in a multispecialty tertiary level hospital, PGIMER, Chandigarh, India. Leadersh Heal Serv. 2011 Feb;24(1):64-73.

21. Sharma A, Kasar PK, Sharma R, Patient SR. Open Access Journal | www.njcmindia.org pISSN 0976 3325 | eISSN 22296816 [Internet]. Vol. 5, National Journal of Community Medicine | Volume. 2014 [cited 2021 May 9]. Available from: www.njcmindia.org

22. Margret Sharmila F, Tharun Kumar P, Darvin Arockia Dass $G$, Subramanian S. An Online Recruitment of Clinicians and Appointment of Patients using Mobile Application. In Institute of Electrical and Electronics Engineers (IEEE); 2021. p. 1383-5. 
23. Dehury RK, Samal J, Coutinho S, Dehury P. How Does the Largely Unregulated Private Health Sector Impact the Indian Mass? J Health Manag [Internet]. 2019 Sep 1 [cited 2021 May 9];21(3):383-93. Available from: https://journals.sagepub.com/doi/10.1177/0972063419 868561

24. Viniya C, Khyathi GV, Sarala KS. To Assess the Marketing Practices on Social Media in Selected Tertiary Care Hospitals in Bangalore. Indian J Public Heal Res Dev [Internet]. 2019 Nov 26 [cited 2021 May 9];10(1 1):725. Available from: https://medicopublication.com/index.php/ijphrd/artic le/view/4113

25. Chen Y, Fay S, Wang Q. The Role of Marketing in Social Media: How Online Consumer Reviews Evolve. J Interact Mark. 2011;25(2):85-94. 